\title{
Health and Performance of Holstein Calves that Suckled or Were Hand-Fed Colostrum and Were Fed One of Three Physical Forms of Starter ${ }^{1}$
}

\author{
S. T. Franklin, D. M. Amaral-Phillips, J. A. Jackson, and A. A. Campbell \\ Animal Sciences Department \\ University of Kentucky, \\ Lexington 40546-0215
}

\begin{abstract}
Intake of colostrum by neonatal calves and early transition to calf starter are two important factors in successful calf programs. Thirty-one Holstein calves were used to determine health and performance of calves that were 1) allowed to remain with their dams for 3 $\mathrm{d}$ and suckle (suckled calves) or were removed from their dams and fed colostrum only by bottle (bottle calves); and were 2) fed ground, pelleted, or textured starters, formulated to be isonitrogenous. Bottle calves were removed from their dams at birth, fed $2.84 \mathrm{~L}$ of colostrum, placed in individual hutches, and fed 1.89 $\mathrm{L}$ of colostrum $12 \mathrm{~h}$ after the first feeding. Suckled calves were removed from their dams after $3 \mathrm{~d}$ and placed in individual hutches. Once calves were housed in hutches, they were fed $2 \mathrm{~L}$ of whole milk twice daily and were provided starters and water beginning on $\mathrm{d}$ 3 . Calves were weighed at birth and weekly for $6 \mathrm{wk}$. Blood samples were obtained at birth, $24 \mathrm{~h}$, and weekly for serum protein determination. Starter intake, fecal scores, and electrolyte treatments were recorded daily. Weaning began when calves had consumed $0.68 \mathrm{~kg}$ starter for $2 \mathrm{~d}$ consecutively. There were no differences in treatment means between suckled and bottle calves for total gain, grain consumption, days with fecal scores $>2$, or electrolyte treatments per calf. Average days to weaning was greater for bottle calves compared with suckled calves. Mean serum protein concentration at $24 \mathrm{~h}$ was greater for bottle $(6.0 \mathrm{~g} / \mathrm{dl})$ compared with suckled calves $(5.8 \mathrm{~g} / \mathrm{dl})$ and only 2 of 15 bottle calves had serum protein concentrations $<5.0 \mathrm{~g} / \mathrm{dl}$ compared with 6 of 16 suckled calves. For starter treatments, calves fed textured starter consumed more total grain, were weaned earlier, and weighed more at $6 \mathrm{wk}$ of age than calves fed pelleted starter. Based on 24-h serum

Received July 18, 2002.

Accepted November 5, 2002.

Corresponding author: S. T. Franklin; e-mail: sfrankli@uky.edu.

${ }^{1}$ This manuscript, 02-07-113, is published with the approval of the director of the Kentucky Agricultural Experiment Station.
\end{abstract}

protein concentrations, transfer of passive immunity was greater for bottle calves compared with suckled calves.

(Key words: colostrum, calf, starter)

Abbreviation key: $\mathbf{B}$ = calves that were fed colostrum only by bottle, GS = ground starter, $\mathbf{P S}=$ pelleted starter, $\mathbf{S}=$ calves that were allowed to suckle colostrum from the dam, $\mathbf{S P C}=$ serum protein concentration, $\mathbf{T S}$ $=$ textured starter.

\section{INTRODUCTION}

Transfer of passive immunity to calves must occur by ingestion of colostrum because sufficient Ig are not passed across the placenta to calves in utero as indicated by practically no Ig present in serum at birth (Franklin et al., 1998). Furthermore, calves have a relatively naive immune system at birth that inhibits their ability to mount an effective immune response as evidenced by the gradual decline of Ig from $24 \mathrm{~h}$ after the first feeding of colostrum through approximately $3 \mathrm{wk}$ of age, and the increase in numbers and percentages of B-cells through 6 wk of age (Nagahata et al., 1991; Franklin et al., 1998). The method used to supply colostrum to a calf can have a major impact on absorption of Ig and, thus, the health, performance, and survival of the calf (Besser et al., 1991). Without question, the successful transfer of passive immunity is an extremely important component for minimizing death losses of calves (Wells et al., 1996). In the United States, the most recent national data indicate that approximately $55 \%$ of calves are allowed to remain with the dam and nurse, while $45 \%$ are removed prior to nursing (NAHMS, 1996). Of those remaining with the dam, $29.4 \%$ of the calves received their first colostrum by nursing the dam, which leaves approximately $25 \%$ of calves receiving first colostrum by a combination of nursing and hand-feeding.

Several studies (Stott et al., 1979b; Nocek et al., 1984; Quigley et al., 1995) have been conducted regarding the most effective method of supplying colostrum. Results 
of these studies are inclusive. Nocek et al. (1984) reported that Holstein calves fed a total of $5.45 \mathrm{~L}$ of colostrum in three feedings by bottle during the first $12 \mathrm{~h}$ after birth had higher serum protein and serum IgG concentrations than calves that remained with their dams for $24 \mathrm{~h}$ and were allowed to suckle. In contrast, Quigley et al. (1995) reported that Jersey calves that suckled had higher serum IgG concentrations compared with calves fed $2 \mathrm{~L}$ of colostrum by bottle in the first $12 \mathrm{~h}$. Stott et al. (1979b) reported greater Ig absorption by Holstein calves allowed to suckle their dam over a 24-h period compared with calves fed by bottle; however, the greatest amount fed by bottle was only $4 \mathrm{~L}$ during the first $12 \mathrm{~h}$ after birth. The results of these studies may be related, at least in part, to the amount of colostrum fed by bottle rather than differences caused by suckling versus bottle-feeding.

Another important component in successful calf rearing programs is an early transition to starter grain. Earlier consumption of starter grains allows for earlier weaning resulting in decreased labor costs and potentially lower feed costs while still achieving adequate growth (Davis and Drackley, 1998b).

Development of rumen papillae is aided by the fermentation of calf starter to VFA (Anderson et al., 1987). Growth of rumen papillae aids in allowing the calf to change from a monogastric form of digestion to one characteristic of adult ruminants (Warner, 1991). When calves consume both calf starter and water at an early age, maturation of the rumen occurs at an earlier age compared with milk-feeding alone. This progress toward maturation of the rumen allows calves to be weaned effectively as early as 4 wk (Anderson et al., 1987).

Few studies have investigated the effect of the physical form of calf starters on intake, performance, and weaning age. Earlier studies (Warner et al., 1973; Warner, 1991) concluded that the ingredients for calf starters should not be finely ground and at least $50 \%$ of the particles should be larger than $1190 \mu \mathrm{m}$. No recently published studies have considered differences in age at weaning or performance of calves fed a traditional ground calf starter compared with commercial pelleted or textured calf starters.

The objective of this study, therefore, was twofold. The first objective was to evaluate differences in health and performance of calves allowed to suckle colostrum from the dam and remain with her for $3 \mathrm{~d}$, a common farm practice, compared with calves fed a total of 4.73 $\mathrm{L}$ of colostrum by bottle only during the first $12 \mathrm{~h}$ after birth. The second objective was to compare weaning age and performance of calves offered either ground, pelleted, or textured starter.

\section{MATERIALS AND METHODS}

\section{Calves and Treatments}

Thirty Holstein calves were blocked by gender and assigned to treatments in a $2 \times 3$ factorial model designed to evaluate effects of method of colostrum consumption and physical form of starter on health and performance. One of the male calves died and was replaced. Calves were born at the University of Kentucky Coldstream Dairy Farm. All animal procedures were in accordance with the Guidelines for the Care and Use of Agricultural Animals in Agricultural Research and Teaching and were approved by the Institutional Animal Care and Use Committee.

Calves were weighed and assigned at birth to treatments of suckled $(\mathbf{S})$ colostrum vs. bottle-fed (B) colostrum (six female and nine male calves/treatment). The $\mathrm{S}$ calves remained with their dam for $3 \mathrm{~d}$ to allow for maximum voluntary intake of Ig before being moved to individual calf hutches. Based on common on-farm procedures, the $\mathrm{S}$ calves were helped to suckle one time or were given a small amount of colostrum (approximately $0.5 \mathrm{~L}$ ), hand-milked from the dam, by bottle to stimulate suckling if they were observed to be slow to stand. Calves in the B group were removed from their dams before suckling, fed 2.84 L of colostrum by bottle, placed in individual calf hutches, and fed another 1.89 $\mathrm{L}$ of colostrum by bottle $12 \mathrm{~h}$ after the first feeding. Fresh colostrum from the dam was used for B calves if it measured greater than $60 \mathrm{mg}$ of $\mathrm{Ig} / \mathrm{ml}$ of colostrum using a colostrometer. Otherwise, high-quality ( $>60 \mathrm{mg}$ of $\mathrm{Ig} / \mathrm{ml}$ ) frozen colostrum was warmed to at least $26^{\circ} \mathrm{C}$ and fed. The first feeding for $\mathrm{B}$ calves averaged less than $3 \mathrm{~h}$ after birth. Thereafter, all calves in hutches were fed $2 \mathrm{~L}$ of whole milk twice daily by bottle or bucket. If calves refused to consume at least $2.6 \mathrm{~L}$ of the first feeding or $1.75 \mathrm{~L}$ of subsequent feedings, they were fed using an esophageal feeder.

At $3 \mathrm{~d}$ of age, calves were assigned to treatments of ground (GS), pelleted (PS), or textured (TS) starters (four female and six male calves/treatment). The GS was a typical calf starter ration with oats (Table 1). The PS and TS were typical commercial type starters with the same ingredients except that the TS contained oats. All starters were formulated to be isonitrogenous at $22 \% \mathrm{CP}$ and all contained $0.07 \%$ lasalocid. The chemical composition of the starters is provided in Table 2. Starter intake was determined daily, and BW were obtained weekly. Ad libitum water was provided for calves from $3 \mathrm{~d}$ of age throughout the study.

Fecal scores and health observations were recorded at the morning feeding. Fluidity of feces was scored on a four-point scale, with $1=$ normal feces to $4=$ watery feces (Larson et al., 1977), and weekly means were cal- 
Table 1. Ingredient composition of calf starter feeds.

\begin{tabular}{lccc}
\hline & & \% of Total Ration DM & \\
\cline { 2 - 4 } Ingredient & Ground & Pelleted & Textured \\
\hline Cracked corn & 27.9 & 39.9 & 27.1 \\
Oats & 35.2 & 0 & 13.1 \\
Soybean meal & 29.5 & 0 & 0 \\
Wheat middlings & 0 & 25.8 & 20.5 \\
Corn gluten meal & 0 & 11.0 & 15.0 \\
Molasses & 4.2 & 5.0 & 8.9 \\
Blood meal & 0 & 5.2 & 3.2 \\
Alfalfa meal & 0 & 2.6 & 2.1 \\
Dried whey & 0 & 2.6 & 2.6 \\
Corn distillers dried grains & 0 & 2.6 & 2.1 \\
Calcitic limestone & 1.1 & 2.7 & 3.0 \\
Salt & 0.84 & 0.84 & 0.68 \\
Dicalcium phosphate & 0.81 & 0.27 & 0.37 \\
Lignin sulfonate & 0 & 0.56 & 0.28 \\
Yeast & 0 & 0.21 & 0.26 \\
Mannanoligosaccharide & $0.11^{1}$ & $0.11^{2}$ & 0.21 \\
Selenium premix & $0.15^{3}$ & $0.13^{4}$ & $0.11^{2}$ \\
Vitamin supplement & $0.03^{5}$ & $0.06^{6}$ & $0.13^{4}$ \\
Trace mineral supplement & 0 & 0 & $0.06^{6}$ \\
Magnesium oxide & 0 & 0.11 & 0.13 \\
Flavoring & 0.07 & 0.07 & 0.11 \\
Lasalocid, 150 gm/kg & & & 0.07 \\
\hline
\end{tabular}

culated. Calves that developed diarrhea (fecal score $>2$ ) were supplemented with an oral electrolyte solution (Biolyte; Pharmacia, Inc., Kalamazoo, MI) approximately 20 min after each milk feeding until fecal scores were $\leq 2$. Fecal samples were sent to the University of Kentucky Livestock Disease Diagnostic Center to identify causative agents. One calf died at the age of 5 wk and was taken to the Diagnostic Center for evaluation.

Calves started the weaning process after they had consumed $0.68 \mathrm{~kg}$ of starter/d for $2 \mathrm{~d}$, consecutively. Calves were weaned by feeding $1 \mathrm{~L}$ of whole milk twice daily for $4 \mathrm{~d}$, followed by complete weaning from milk on $\mathrm{d} 5$.

\section{Sample Collection and Analysis}

Blood samples were obtained in Vacutainer tubes (Becton Dickinson Vacutainer Systems, Franklin Lakes, NJ) via jugular venipuncture as soon after birth as possible, at $24 \mathrm{~h}$, and weekly for 6 wk. Serum was harvested from 10-ml Vacutainer tubes without antico- agulant for immediate determination of total serum protein concentrations (SPC) using a handheld refractometer (Westover Model RHC-200ATC, China). The remainder of the serum was frozen at $-20^{\circ} \mathrm{C}$ until analy-

Table 2. Nutrient analysis of calf starter feeds.

\begin{tabular}{lccc}
\hline Nutrient & Ground & Pelleted & Textured \\
\hline $\mathrm{DM}, \%$ & 88.9 & 87.6 & 87.0 \\
$\mathrm{CP} \%$ & 21.2 & 22.2 & 25.8 \\
$\begin{array}{l}\text { Calculated } \mathrm{NE}_{\mathrm{M}},{ }^{1} \\
\text { (Mcal/kg) }\end{array}$ & 2.00 & 1.98 & 2.00 \\
Calculated $\mathrm{NE}_{\mathrm{G}}{ }^{2}{ }^{2}$ & & & \\
(Mcal/kg) & 1.34 & 1.34 & 1.36 \\
$\mathrm{ADF}, \%$ & 7.4 & 7.4 & 7.9 \\
$\mathrm{NDF}, \%$ & 13.9 & 16.2 & 16.9 \\
$\mathrm{Crude}$ fat, \% & 3.9 & 4.2 & 4.7 \\
$\mathrm{Ca}, \%$ & 0.91 & 1.26 & 1.61 \\
$\mathrm{P}, \%$ & 0.55 & 0.56 & 0.64 \\
$\mathrm{Mg}, \%$ & 0.21 & 0.24 & 0.29 \\
$\mathrm{~K}, \%$ & 0.97 & 0.74 & 0.71 \\
$\mathrm{Na}, \%$ & 0.33 & 0.44 & 0.42 \\
\hline
\end{tabular}

${ }^{1}$ Net energy maintenance.

${ }^{2}$ Net energy growth. 
sis for IgM and IgG concentrations by ELISA (Franklin et al., 1995). Serum samples were diluted 1:100,000 ( $\mathrm{vol} / \mathrm{vol}$ ) for determination of IgM and 1:400,000 for determination of IgG.

\section{Statistical Analysis}

Analysis for variables with only treatment means. The general linear models procedure of SAS (1996) was used to determine if differences among treatment means existed. Method of feeding colostrum, physical form of starter, and gender were tested as main effects and there were no interactions between method of feeding colostrum and physical form of starter. One calf died during the study and was not included in the analyses related to physical form of calf starter because the calf was sick during most of the study and would have skewed the data relating to feed intake and weight gain. Six-week means relating to physical form of the calf starter were compared using pairwise $t$-tests. Differences among treatment means were considered significant at $P<0.05$.

Analysis for variables with repeated measures. Data with repeated measures were analyzed using the mixed model procedure of SAS (SAS/STAT Software, 1996). Method of colostrum feeding, physical form of starter, gender, and time were tested as main effects. A covariate was included in the model when appropriate but was removed from the model when not significant. All two-way and three-way effects were tested and removed from the model when not significant. There were no significant interactions between method of feeding colostrum and physical form of starter for any of the variables analyzed. Differences were considered significant at $P<0.05$ unless otherwise stated.

\section{RESULTS AND DISCUSSION}

\section{Method of Colostrum Consumption}

Thirty of 31 calves completed the study through 6 wk of age. One male calf, which was fed colostrum by suckling, died at 5 wk of age after prolonged diarrhea and was not included in data analyses related to feed intake and weight gain. The calf was included in data relating to health parameters such as fecal scores, electrolyte treatments, serum protein concentrations, and serum IgM and IgG concentrations that would be directly related to method of feeding colostrum. Of the $15 \mathrm{~B}$ calves, only three calves required the use of an esophageal feeder to supply part of the first allotment of colostrum. An esophageal feeder was only used if calves refused more than $0.24 \mathrm{~L}$ of colostrum after multiple attempts to feed the calf by nipple-bottle.
Lactation numbers were similar for the dams of the $\mathrm{S}$ and $\mathrm{B}$ calves. For the dams of the $\mathrm{S}$ calves, eight were first lactation cows and eight were second or greater lactation cows. For the dams of the B calves, seven were first lactation and eight were second or greater lactation, with average colostrum quality of 87 and 89 $\mathrm{mg} / \mathrm{ml}$, respectively. Six dams of B calves either were first lactation animals that were difficult to milk, did not produce enough colostrum, or colostrum quality was low which required the use of frozen colostrum to provide calves with $2.84 \mathrm{~L}$ at birth and $2 \mathrm{~L}$ at $12 \mathrm{~h}$ after birth. Similar problems with low volume or low quality colostrum for dams of calves that are allowed to suckle naturally would place those calves at risk for failure of passive transfer of immunity.

Performance of S and B calves is presented in Table 3 . The average number of days to weaning was greater $(P=0.1)$ for B calves compared with $\mathrm{S}$ calves. One explanation for this difference might be that calves left with their dams became accustomed to eating at frequent intervals compared to B calves, which were fed milk twice daily. If calves became accustomed to eating frequently, once they were restricted to twice daily feedings of milk, they may have continued to search for food at frequent intervals and become familiar with consuming grain earlier. Initial and final BW were similar for S and B calves (Table 3). Total weight gain, total grain consumed, and total milk consumed were not different $(P>0.1)$ between treatments even though $\mathrm{S}$ calves weaned at an earlier age.

Serum protein concentrations measured at birth were used for covariate analysis and averaged $4.2 \pm 0.5$ $\mathrm{g} / \mathrm{dl}$ for B calves and $4.4 \pm 0.3 \mathrm{~g} / \mathrm{dl}$ for S calves. Mean SPC did not differ between treatments; however, there was a significant $(P=0.03)$ treatment $\times$ day effect for method of feeding colostrum (Figure 1). At $24 \mathrm{~h}$ after birth, the SPC was greater $(P=0.03)$ for B calves compared with $\mathrm{S}$ calves. The SPC at wk 1 tended $(P=0.1)$ to be greater for $\mathrm{B}$ calves compared with $\mathrm{S}$ calves. By wk 2, the mean SPC for both groups of calves was approximately $5.5 \mathrm{~g} / \mathrm{dl}$ and remained fairly constant through the rest of the study. The percent increase in SPC by $24 \mathrm{~h}$ after the first feeding for B calves was $42.4 \%$ with only 2 of the $15 \mathrm{~B}$ calves having SPC less than $5.0 \mathrm{~g} / \mathrm{dl}$. In comparison, the mean increase in SPC for $\mathrm{S}$ calves from birth to $24 \mathrm{~h}$ was only $28.5 \%$ and six of the 16 calves (37.5\%) allowed to suckle had SPC of $5.0 \mathrm{~g} / \mathrm{dl}$ or less; indicating greater transfer of passive immunity to B calves and less than desired transfer to S calves (Table 3). A SPC of $5.5 \mathrm{~g} / \mathrm{dl}$ has been suggested as an indicator of minimal colostrum intake (Naylor et al., 1977; Wilson et al., 1994). Tyler et al. (1998), however, indicated that an SPC of $5.0 \mathrm{~g} / \mathrm{dl}$ was a more reasonable goal based on the relative risk of mortality 
Table 3. Performance through 6 wk of age for calves that suckled (S) their dam from birth through $3 \mathrm{~d}$ of age compared with calves removed from the dam and fed colostrum by bottle (B). ${ }^{1}$

\begin{tabular}{lcccc}
\hline Variable & $\mathrm{B}$ & $\mathrm{S}$ & $\mathrm{SEM}$ & $\mathrm{P}$ \\
\hline Average days to weaning & & & \\
Gain, kg & 35.0 & 31.5 & 1.01 & 0.10 \\
Initial BW, kg & 21.3 & 20.3 & 0.82 & 0.55 \\
Final BW, kg & 39.2 & 40.9 & & \\
Total grain consumed, kg & 60.5 & 61.2 & & \\
Total milk consumed, L & 14.2 & 17.7 & 1.37 & 0.21 \\
Increase in serum protein from birth to $24 \mathrm{~h}, \%$ & 133.5 & 128.5 & 2.77 & 0.37 \\
Days with fecal scores >2 & 42.4 & 28.5 & 3.2 & 0.04 \\
Electrolyte treatments/calf & 4.9 & 5.8 & 0.78 & 0.58 \\
\hline
\end{tabular}

${ }^{1}$ Values are means for 15 calves/treatment except for serum protein values, fecal scores, and electrolyte treatments for $\mathrm{S}$ calves which include an additional calf that died at 5 weeks of age.

${ }^{2}$ Weaning was started when calves had consumed $0.68 \mathrm{~kg}$ of starter $/ \mathrm{d}$ for $2 \mathrm{~d}$, consecutively.

for calves with SPC less than $5.0 \mathrm{~g} / \mathrm{dl}$ compared with calves with $\mathrm{SPC}>5.0 \mathrm{~g} / \mathrm{dl}$. In a review of passive transfer of immunity in calves by Weaver et al. (2000), the authors indicated that the percent of calves with SPC $<5.0 \mathrm{~g} / \mathrm{dl}$ was a better indicator of risk of mortality than mean serum IgG or mean SPC.

Selman et al. (1970) reported characteristics of calves allowed to suckle. They observed 30 cow and calf pairs (10 each of beef cows, dairy heifers, and dairy cows) for $8 \mathrm{~h}$ postpartum. Seven of the 30 calves (23\%) did not suckle within the $8 \mathrm{~h}$ period. Selman et al. (1970) also reported that of the calves that suckled, the beef calves suckled at a mean of 81.4 min after birth, whereas the calves from dairy heifers required a mean of $218.3 \mathrm{~min}$ and the calves from the dairy cows required $261.1 \mathrm{~min}$. The authors suggested that dairy cows have been bred for high milk production, resulting in more developed mammary glands compared with wild ungulates, making dairy cows harder to suckle. Abel Francisco and
Quigley (1993) reported a decrease in apparent efficiency of absorption of Ig within $1 \mathrm{~h}$ after birth. The delay in consumption of colostrum that can occur in dairy calves allowed to suckle compared with calves fed by bottle may have contributed to the lower SPC at 24 $\mathrm{h}$ in $\mathrm{S}$ calves compared with $\mathrm{B}$ calves. In the current study, calves that were not observed to be standing and attempting to nurse were fed a small amount of maternal colostrum by bottle or were aided in suckling so that differences in Ig absorption between $\mathrm{S}$ and $\mathrm{B}$ calves were not as great as may have occurred if calves were left to suckle alone. The calf that died in the current study either failed to suckle the dam or failed to absorb immunoglobulins. The calf was observed to be standing and moving about the stall after birth, but SPC did not increase from birth to $24 \mathrm{~h}$.

Mean serum IgM and IgG concentrations did not differ between S and B calves (Figure 2), and there was

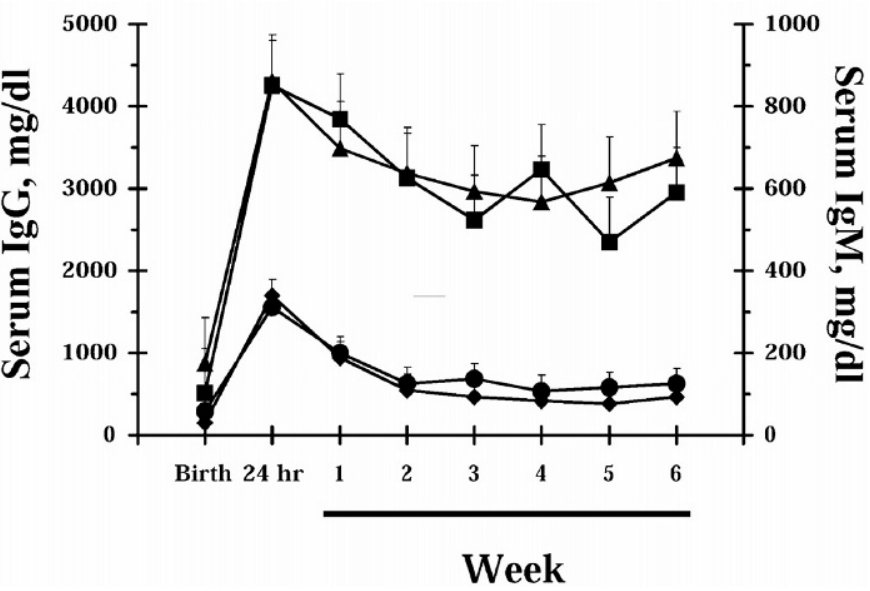

Figure 2. Serum IgG concentrations for suckled (A) and bottlefed (⿶) calves as well as serum IgM concentrations for suckled ( and bottle-fed $(\bullet)$ calves. Data are presented as least squares means \pm SEM. 
not a treatment $\times$ day interaction for method of feeding colostrum. Beginning serum IgM and IgG concentrations were tested as covariates but were removed from the model. In general, the shape of the curves for SPC, and serum IgM and IgG concentrations were similar; however, there was greater variability among calves in the concentrations of IgG and IgM, as measured by the ELISA assay, compared with the variability among calves for SPC as determined by a refractometer. Based on the ELISA assay, three of the S calves had IgG concentrations below $1 \mathrm{~g} / \mathrm{dl}$ at $24 \mathrm{~h}$ compared with only $1 \mathrm{~B}$ calf with a serum IgG concentration below $1 \mathrm{~g} / \mathrm{dl}$. Values for SPC, and serum IgM and IgG concentrations were similar to previously reported values (Franklin et al., 1998).

The mean number of days calves had fecal scores greater than 2 and the mean number of electrolyte treatments per calf did not differ because of method of colostrum consumption (Table 3). Most incidences of fecal scores greater than 2 occurred during wk 2 and 3 , which is consistent with previous reports (Quigley et al., 1995; Franklin et al., 1998). Whereas the differences in SPC did not translate into significantly more days with diarrhea or increased electrolyte treatments, the calves in the current study were relatively healthy. Pathogens detected from fecal samples of calves with diarrhea were Cryptosporidium parvum, coronavirus, and rotavirus. The suspected cause of diarrhea in most of the calves, Cryptosporidium parvum, is not controlled by ingestion of colostrum (Harp et al., 1990). Under less sanitary conditions, the lower transfer of passive immunity to the $\mathrm{S}$ calves compared with the $\mathrm{B}$ calves may have resulted in increased calf morbidity or mortality.

Results from previous studies to determine the most effective method of supplying colostrum to calves are inconclusive. Many methods have been considered. Logan et al. (1981), using Friesian calves, compared serum Ig concentrations of calves that suckled only with those of calves that were left with the dam but were fed approximately $1 \mathrm{~L}$ of hand-milked colostrum by bottle for the first feeding. Results indicated that only $23.2 \%$ of the calves allowed to suckle naturally acquired sufficient Ig, whereas $42.3 \%$ of calves fed $1 \mathrm{~L}$ of colostrum by hand and also were left with the dam to suckle acquired sufficient serum Ig concentrations. Nocek et al. (1984) reported that Holstein calves fed a total of $5.45 \mathrm{~L}$ of colostrum in three feedings by bottle during the first $12 \mathrm{~h}$ after birth had higher serum protein and serum IgG concentrations than calves that suckled. Besser et al. (1991) reported that failure of passive transfer (serum protein $<5.0 \mathrm{~g} / \mathrm{dl}$ or IgG $<1.0 \mathrm{~g} / \mathrm{dl}$ ) occurred in $61 \%$ of Holstein calves allowed to suckle at birth compared to $19 \%$ failure of passive transfer in calves fed $1.9 \mathrm{~L}$ by bottle at birth and only $11 \%$ failure of passive transfer in calves fed $2.84 \mathrm{~L}$ by using an esophageal feeder at birth.

In contrast, Quigley et al. (1995) reported that Jersey calves that suckled had higher serum IgG concentrations than did calves fed by bottle. The Jersey calves fed from bottles, however, were limited to only $2 \mathrm{~L}$ of colostrum (approximately 8\% of BW) before obtaining the 24-h blood sample for analysis of passive transfer. Calves allowed to suckle the dam may have obtained a greater volume of colostrum than calves fed from a bottle, resulting in improved transfer of passive immunity for calves allowed to suckle. Stott et al. (1979b) also reported greater Ig absorption by Holstein calves allowed to suckle compared with calves fed by bottle; however, the amounts fed by bottle were limited to 1 , 2 , or $4 \mathrm{~L}$ during the first $12 \mathrm{~h}$ after birth. For the studies in which calves fed by bottle had better transfer of passive immunity, the amount fed to Holstein calves by bottle during the first $12 \mathrm{~h}$ varied considerably with volumes of 5.45 L (Nocek et al., 1984), 4.74 L (present study), and either $2.84 \mathrm{~L}$ at birth or $3.8 \mathrm{~L}$ during the first $12 \mathrm{~h}$ (Besser et al., 1991). In general, it appears that a volume of $2 \mathrm{~L}$ of colostrum at birth is the minimum that should be fed by bottle to a Holstein calf when the calf will only be fed twice during the first 12 $\mathrm{h}$ of life. In the present study using Holstein calves, seven of 15 calves voluntarily consumed $2.84 \mathrm{~L}$ by bottle during the first feeding and five more calves consumed between 2.6 and $2.84 \mathrm{~L}$ voluntarily. Only three calves required the use of an esophageal feeder for administration of colostrum. Therefore, $2.84 \mathrm{~L}$ of colostrum is likely the volume that should be fed at birth to maximize transfer of passive immunity without resorting to forced feeding of colostrum with an esophageal feeder.

By removing calves from their dam and hand-feeding $2.84 \mathrm{~L}$ of high-quality colostrum as soon as possible after birth, calves should be exposed to fewer diseasecausing organisms and producers can insure that calves receive colostrum. Producers also can insure calves ingest colostrum before gut closure, which occurs by about $24 \mathrm{~h}$ after birth (Stott et al., 1979a). Additionally, although feeding $4 \mathrm{~L}$ of colostrum at birth resulted in increased concentrations of Ig in serum compared with feeding $2 \mathrm{~L}$ of colostrum (Morin et al., 1997), calves may not voluntarily consume $4 \mathrm{~L}$ and must be fed using an esophageal feeder. Morin et al. (1997) reported that 7 of 11 calves (64\%) fed $4 \mathrm{~L}$ at birth required the use of an esophageal feeder for one or more meals compared with 10 of 40 calves ( $25 \%$ ) fed $2 \mathrm{~L}$ of colostrum. Feeding $2.84 \mathrm{~L}$ at birth provided greater transfer of passive immunity compared to suckling, without requiring the use of an esophageal feeder for most of the calves. 
Table 4. Performance through 6 wk of age of calves fed either ground (GS), pelleted (PS), or textured (TS) starter $(n=10 /$ treatment $)$.

\begin{tabular}{|c|c|c|c|c|}
\hline Variable & GS & PS & TS & SEM \\
\hline Average days to weaning ${ }^{1}$ & $31.9^{\mathrm{ab} 2}$ & $36.8^{\mathrm{a}}$ & $31.1^{\mathrm{b}}$ & 1.01 \\
\hline Total gain, kg & $20.9^{\mathrm{ab}}$ & $18.5^{\mathrm{b}}$ & $23.1^{\mathrm{a}}$ & 0.86 \\
\hline \multicolumn{5}{|l|}{ Average daily gain } \\
\hline 0 through $6 \mathrm{wk}, \mathrm{kg} / \mathrm{d}$ & 0.50 & 0.44 & 0.55 & \\
\hline 0 through $3 \mathrm{wk}, \mathrm{kg} / \mathrm{d}$ & 0.28 & 0.23 & 0.33 & \\
\hline 4 through 6 wk, kg/d & 0.71 & 0.64 & 0.78 & \\
\hline Total grain consumed, kg & $17.6^{\mathrm{ab}}$ & $11.2^{\mathrm{b}}$ & $19.0^{\mathrm{a}}$ & 1.38 \\
\hline \multicolumn{5}{|l|}{ Grain intake by period } \\
\hline 0 through 3 wk, kg & 1.8 & 0.8 & 1.5 & 0.23 \\
\hline 4 through $6 \mathrm{wk}, \mathrm{kg}$ & $15.8^{\mathrm{ab}}$ & $10.4^{\mathrm{b}}$ & $17.5^{\mathrm{a}}$ & 1.22 \\
\hline Total milk consumed, L & $129^{\mathrm{ab}}$ & $139^{\mathrm{a}}$ & $125^{\mathrm{b}}$ & 2.76 \\
\hline Days with fecal scores >2 & 5.6 & 5.5 & 3.9 & 0.74 \\
\hline Electrolyte treatments/calf & 8.8 & 8.9 & 4.8 & 1.27 \\
\hline
\end{tabular}

${ }^{1}$ Weaning was started when calves had consumed $0.68 \mathrm{~kg}$ of starter/d for $2 \mathrm{~d}$.

${ }^{2}$ Values with different superscripts differ at $P \leq 0.05$.

\section{Physical Form of Calf Starter}

Performance of calves based on physical form of starter is provided in Table 4. Calves fed TS required fewer $(P=0.03)$ days to achieve intakes of $0.68 \mathrm{~kg} / \mathrm{d}$ than calves fed PS. Calves fed GS tended $(P=0.07)$ to require fewer days to intakes of $0.68 \mathrm{~kg} / \mathrm{d}$ than calves fed PS. Total gain was greater $(P=0.02)$ for calves fed TS compared with calves fed PS, with greater average daily gains occurring for all groups from 4 through 6 wk of age compared with birth through 3 wk of age. Total grain consumed was greater $(P=0.03)$ for calves fed TS compared with PS and tended to be greater $(P$ $=0.07$ ) for calves fed GS compared with calves fed PS. Starter intake during the first $3 \mathrm{wk}$ of life did not differ based on physical form of starter; however, calves did begin to consume starter before 3 wk of age. From 4 through 6 wk of age, calves fed TS consumed approximately $72 \%$ more starter compared with calves fed PS. Calves fed PS consumed more total milk $(P=0.04)$ than did calves fed TS. For the 6 wk period, calves fed TS consumed approximately $80 \%$ more starter and $11 \%$ less milk than calves fed PS. The number of days calves experienced diarrhea or were supplemented with electrolytes did not differ $(P>0.1)$ among treatments.

There was a significant $(P=0.005)$ treatment $\times$ week interaction for physical form of starter (Figure 3). During wk 5, calves fed GS and TS consumed more $(P<$ 0.05 ) starter at approximately $0.7 \mathrm{~kg} / \mathrm{d}$ compared with calves consuming PS at approximately $0.4 \mathrm{~kg} / \mathrm{d}$. During wk 6, the difference in starter consumption between TS and PS increased, as a result of earlier weaning from whole milk, so that calves fed TS consumed approximately $35 \%$ more starter than calves fed PS. Calves fed TS, GS, and PS consumed an average of 1.4, 1.2 , and $0.8 \mathrm{~kg} / \mathrm{d}$, respectively, during wk 6 .
Beginning BW was tested as a covariate for influence of calf starter on weekly BW but did not significantly affect the model and was removed. There was a tendency for a treatment $\times$ day interaction $(P=0.06)$ for the effect of physical form of starter on weekly BW. Mean BW gradually increased throughout the trial. On $\mathrm{d} 42$, calves fed TS had greater $(P=0.03)$ BW compared with calves fed PS (Figure 4). Calves did not suffer BW losses during wk 2 and 3, when episodes of diarrhea are especially prevalent. Calves also did not experience weight loss during the weaning period. All calves had reached starter intakes of at least $0.68 \mathrm{~kg} / \mathrm{d}$ by $42 \mathrm{~d}$ of age and were weaned.

Performance of calves was affected by the amount of starter feed consumed. Calves that consumed greater amounts of starter, those fed TS, had improved growth rates, consumed less milk, and were weaned sooner

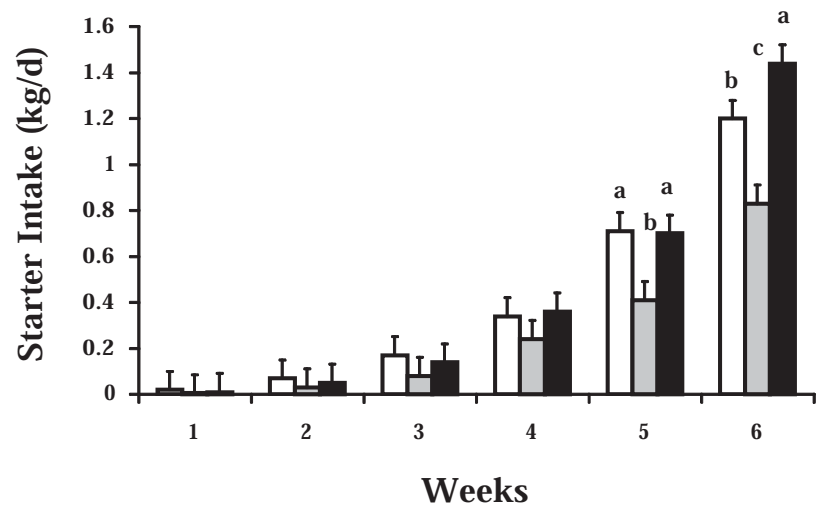

Figure 3. Daily calf starter intake (kg/d) by treatment for calves fed either ground (open bar), pelleted (grey bar), or textured (black bar) starter $(n=10 /$ trt $)$ through $42 \mathrm{~d}$ of age. Data are presented as least squares means \pm SEM. Bars with different letters differ at $P$ $<0.05$. 


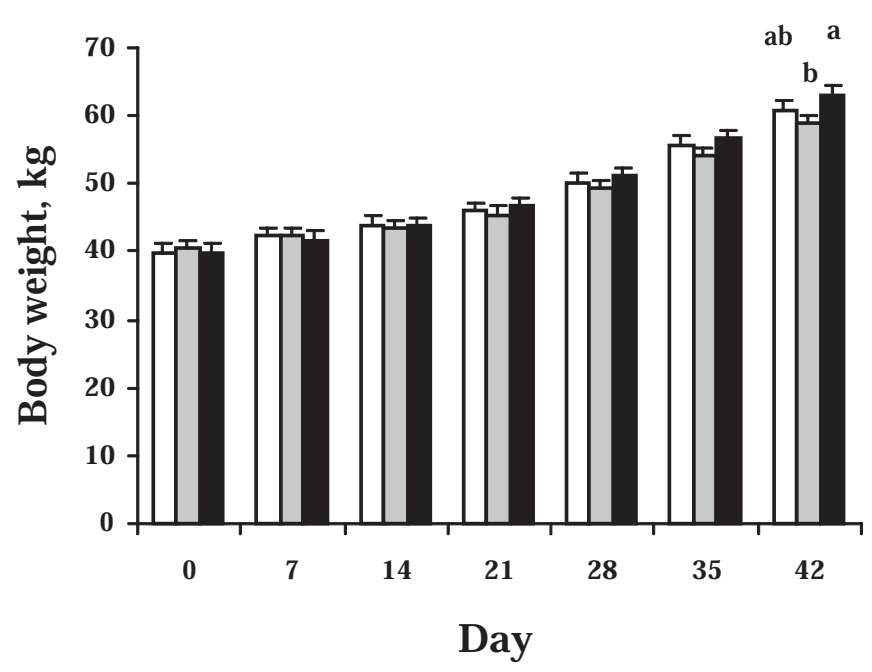

Figure 4. Body weights of calves fed either ground (open bar), pelleted (grey bar), or textured (black bar) starter $(n=10 /$ trt) through $42 \mathrm{~d}$ of age. Data are presented as least squares means \pm SEM. Bars with different letters differ at $P<0.1$.

than calves fed PS, which ultimately would result in decreased costs for dairy producers. Warner et al. (1973) reported that calves fed starter in meal form have greater intakes and daily weight gain than calves fed starter in pelleted form. The authors attributed the improved intake and performance obtained with meal to greater particle size of the starter and increased rumination. Beharka et al. (1998) fed calves a hay and grain diet either unground or ground to $1 \mathrm{~mm}$ particle size. They reported that calves fed the ground diet had less total surface area associated with dorsal papillae in the rumen compared with calves fed the diet that was not ground. Owen and Larson (1986), however, compared intake of calves fed starter as a meal form with the same mix in pelleted form and did not find differences in starter intake or performance. Pelleted and textured commercial starters had not been previously compared. The greater intakes and performance achieved with TS compared to PS may have been related to particle size of the PS compared to the TS.

It is possible that the greater protein content of the TS (25.8\% CP, Table 2) may have partially accounted for the greater BW gains compared with calves fed the PS (22.2\% CP). Akayezu et al. (1994), however, reported that maximum growth of calves was achieved at $19.6 \%$ $\mathrm{CP}$ with no additional advantage of higher protein content.

Nationally, calves are weaned at an average of 8.7 wk of age (NAHMS, 1996), however, calves can be safely and effectively weaned by $4 \mathrm{wk}$ of age (Anderson et al., 1987). In the present study, calves fed GS and TS were voluntarily consuming at least $0.68 \mathrm{~kg}$ of starter feed by an average of approximately $4.5 \mathrm{wk}$ of age and were weaned. Weaning at 4 to $5 \mathrm{wk}$ of age compared with $8.7 \mathrm{wk}$ of age could result in substantial savings for producers because starter feed generally is less expensive than milk replacer or tank milk (Heinrichs, 1993). Additionally, less labor is required to feed calves grain than milk or milk replacer. Finally, ruminal development occurs at an earlier age in calves weaned earlier (4 wk of age) compared with calves weaned at a more conventional age of $6 \mathrm{wk}$ (Anderson et al., 1987). If calves prefer textured or ground starter over pelleted starter, consumption and performance could improve and age at weaning, health, and labor costs could decrease.

\section{CONCLUSIONS}

The number of calves with SPC of less than $5.0 \mathrm{~g} /$ $\mathrm{dl}$ for $\mathrm{S}$ calves indicates a lower transfer of passive immunity compared with B calves and a potential for increased morbidity and mortality for calves allowed to suckle. These differences likely would have been greater if the $\mathrm{S}$ calves had not been aided at birth in suckling. This study lends support to current recommendations for removing the calf from the dam and feeding at least $2.84 \mathrm{~L}$ by nipple bottle. Physical form of the starter supplied to calves can have an impact on performance and age at weaning. Adequate transfer of passive immunity and decreased age at weaning with improved performance of calves will improve profitability of heifer rearing as well as decrease calf losses through mortality.

\section{ACKNOWLEDGMENTS}

The authors would like to acknowledge the excellent technical assistance of Bernice Smith and the invaluable aid of the University of Kentucky dairy farm crew.

\section{REFERENCES}

Abel Francisco, S. F., and J. D. Quigley, III. 1993. Serum immunoglobulin concentration in response to maternal colostrum and colostral supplementation in dairy calves. Am. J. Vet. Res. 54:10511054.

Akayezu, J. M., J. G. Linn, D. E. Otterby, W. P. Hansen, and D. G. Johnson. 1994. Evaluation of calf starters containing different amounts of crude protein for growth of Holstein calves. J. Dairy Sci. 77:1882-1889.

Anderson, K. L., T. G. Nagaraja, and J. L. Morrill. 1987. Ruminal and metabolic development in calves weaned conventionally or early. J. Dairy Sci. 70:1000-1005.

Beharka, A. A., T. G. Nagaraja, J. L. Morrill, G. A. Kennedy, and R. D. Klemm. 1998. Effects of form of the diet on anatomical, microbial, and fermentative development of the rumen of neonatal calves. J. Dairy Sci. 81:1946-1955.

Besser, T. E., C. C. Gay, and L. Pritchett. 1991. Comparison of three methods of feeding colostrum to dairy calves. J. Am. Vet. Med. Assoc. 198:419-422. 
Davis, C. L. and J. K. Drackley, 1998b. Starter feed: Importance, composition, and intake. Pages 283-206 in The Development, Nutrition and Management of the Young Calf. Iowa State University Press, Ames.

Franklin, S. T., C. E. Sorenson, and D. C. Hammell. 1998. Influence of vitamin A supplementation in milk on growth, health, concentrations of vitamins in plasma, and immune parameters of calves. J. Dairy Sci. 81:2623-2632.

Franklin, S. T., J. W. Young, B. J. Nonnecke, and R. L. Horst. 1995. Administration of 13-cis retinoic acid to dairy cattle: 2. Phenotype of blood leukocytes and production of immunoglobulin. J. Dairy Sci. 78:70-76.

Harp, J. A., D. B. Woodmansee, and H. W. Moon. 1990. Resistance of calves to Crytptosporidium parvum: Effects of age and previous exposure. Infect. Immunol. 58:2237-2240.

Heinrichs, A. J. 1993. Raising dairy replacements to meet the needs of the 21st century. J. Dairy Sci. 76:3179-3187.

Larson, L. L., F. G. Owen, J. L. Albright, R. D. Appleman, R. C. Lamb, and L. D. Muller. 1977. Guidelines toward more uniformity in measuring and reporting calf experimental data. J. Dairy Sci.60:989-991.

Logan, E. F., B. D. Muskett, and R. J. Herron. 1981. Colostrum feeding of dairy calves. Vet. Rec. 108:283-284.

Morin, D. E., G. C. McCoy, and W. L. Hurley. 1997. Effects of quality, quantity, and timing of colostrum feeding and addition of a dried colostrum supplement on immunoglobulin $\mathrm{G}_{1}$ absorption in Holstein bull calves. J. Dairy Sci. 80:747-753.

National Animal Health Monitoring System. 1996. Part I. Reference of 1996 Dairy Management Practices. USDA:APHIA:VS, Ft. Collins, CO.

Nagahata, H., N. Kojima, I. Higashitani, H. Ogawa, and H. Noda. 1991. Postnatal changes in lymphocyte function of dairy calves. J. Vet. Med. 38:49-54.

Naylor, J. M., D. S. Kronfeld, S. Bech-Nielsen, and R. C. Bartholomew. 1977. Plasma total protein measurement for prediction of disease and mortality in calves. J. Am. Vet. Med. Assoc. 171:635-638.

Nocek, J. E., D. G. Braund, and R. G. Warner. 1984. Influence of neonatal colostrum administration, immunoglobulin, and contin- ued feeding of colostrum on calf gain, health, and serum protein. J. Dairy Sci. 67:319-333.

Owen, F. G., and L. L. Larson. 1986. Effect of probiocin and starter preparation on calf performance. Coop. Ext. Ser. Univ. Nebr. 1986:36-37.

Quigley, J. D., III, K. R. Martin, D. A. Bemis, L. N. D. Potgieter, C. R. Reinemeyer, B. W. Rohrbach, H. H. Dowlen, and K. C. Lamar. 1995. Effects of housing and colostrum feeding on serum immunoglobulins, growth, and fecal scores of Jersey calves. J. Dairy Sci. 78:893-901.

Selman, I. E., A. D. McEwan, and E. W. Fisher. 1970. Studies on natural suckling in cattle during the first eight hours post partum II. Behavioural studies (calves). Anim. Behav. 18:284-289.

Stott, G. H., D. B. Marx, B. E. Menefee, and G. T. Nightengale. 1979a. Colostral immunoglobulin transfer in calves. I. Period of absorption. J. Dairy Sci. 62:1632-1638.

Stott, G. H., D. B. Marx, B. E. Menefee, and G. T. Nightengale. 1979b. Colostral immunoglobulin transfer in calves. IV. Effect of suckling. J. Dairy Sci. 62:1908-1913.

Tyler, J. W., D. D. Hancock, S. E. Wiksie, S. L. Holler, J. M. Gay, and C. C. Gay. 1998. Use of serum protein concentration to predict mortality in mixed-source dairy replacement heifers. J. Vet. Intern. Med. 12:79-83.

Warner, R. G. 1991. Nutritional factors affecting the development of a functional ruminant-A historical perspective. Proc. Cornell Nutr. Conf., 1-12. Ithaca, NY: Cornell University.

Warner, R. G., J. C. Proter, and S. T. Slack. 1973. Calf starter formulation for neonatal calves fed no hay. Proc. Cornell Nutr. Conf., 116-122. Ithaca, NY: Cornell University.

Weaver, D. M., J. W. Tyler, D. C. VanMetre, D. E. Hostetler, and G. M. Barrington. 2000. Passive transfer of colostral immunoglobulins in calves. J. Vet. Intern. Med. 14:569-577.

Wells, S. J., D. A. Dargatz, and S. L. Ott. 1996. Factors associated with mortality to 21 days of life in dairy heifers in the United States. Prev. Vet. Med. 29:9-19.

Wilson, L. L., C. L. Egan, and T. R. Drake. 1994. Blood, growth, and other characteristics of special-fed veal calves in private cooperator herds. J. Dairy Sci. 77:2477-2485. 